\title{
Balanced Scorecard Implementation in Restaurant Management
}

\author{
Fitri Abdillah and Ida Bagus Putu Wira Diana \\ International Bali Tourism Institute, Bali \\ Corresponding Author: fitri adie@yahoo.com
}

\section{ARTICLE INFO}

Received

28 December 2017

Accepted

13 March 2018

Available online

30 March 2018

\begin{abstract}
Balanced scorecard (BSC) is tools that are widely used to measure company performance including in the hospitality industry. It's widely applied because it's simple, easy, and effective especially in startup business. The objective of this research is to measure the restaurant performance by using BSC. Data observed by participant observation, unstructured interviews, and documentation that produced three measurement models. This data analyzed by descriptive analysis and simple linear correlation to prove the relationship between each perspective of BSC. This study proposed three correlative models that designed from selected indicator of four BSC perspectives. The results show (i) The first model: employee absentee rate is positively correlated with customer complaints 0.417, customer complaints are positively correlated with labor cost percentage of 0.387 , and labor costs are negatively correlated with net profit margin of -0.395 ; (ii) The second model: the percentage of foodstuff price are negatively correlated with total number of customers -0.607 , total number of customers are negatively correlated with food loss -0.916 , food loss are negatively correlated with employee trained percentage -0.378 ; and (iii) The third model: revpash are positively correlated with average check of 0.994 , average check are positively correlated with cover per labor hour of 0.800 , and cover per labor hour is positively correlated revenue per employee with of 0.837 . The all result indicates that BSC models could be implemented to measure restaurant performance by selecting indicator of each perspective. It means that a change in one perspective leads to disruption of other perspectives, so that the restaurant management must consider various factors if it has to make a decision or strategies. The BSC model can help the management in formulating strategies to improve restaurant performance.
\end{abstract}

Keyword: balanced scorecard, restaurant performance indicator

\section{Introduction}

\section{Background}

Restaurant business is predicted to be continued and develop because food and beverage is a basic requirement that must be fulfilled everyone. Streanise (2012) mentions that, the lifestyle of modern humans consider eating and drinking is no longer just to survive, but also has shifted into a lifestyle, a recreational event, a social event, or even a pride. Research results from the National Restaurant Association (NRA), which is the largest restaurant association in the world, stated that restaurant industry revenue in the United States is projected to reach 798.7 billion dollars in 2017, which increased 4.3 percent compared with the previous year amounted to 766 billion dollars. It is also supported by the Toast Pos survey, involving 450 food and beverage entrepreneurs in 
America, 92\% of them are optimistic that their business will improve. Respond of these conditions, innovation of products and services is not enough to ensure the success of a restaurant, without balanced with a good management system. This argument is supported by Marr's (2014) that management can work well when all aspects of a business can be measured. Performance measurement can be used as an important navigational tool by managers to understand the condition of a managed company is leading to success or otherwise. According to Rangkuti (2011) in order to measure future performance, comprehensive measurement is needed which includes four perspectives, financial, consumer, internal business processes, learning and growth, because financial performance is the result or result of nonfinancial performance. From these statements can be explained that the measurentment comprehensive on performance is one of the important aspects in formulating strategies to manage the company more effectively and efficiently in the face of competition. Currently, traditional performance measurement is less relevant as it only focuses on a financial perspective that causes the company's orientation only on short-term profits and tends to ignore the longterm viability of the company.

In terms of increasing revenue, restaurant management undertakes a strategy of improving service quality by developing employee competency through employee training programs targeted at least two topics per month, but management has not measured the level of employee productivity so that the effectiveness of training outcomes can not be measured clearly where the training is done to improve employee productivity or not. In addition, the management has not made a measurement of the percentage of labor costs and employee absenteeism, even though these indicators have an immediate impact on the amount of profit generated. According to Lynn (2017) control the labor costs is one way to increase profits. From the description can be explained that the performance measurement system conducted by the management not enough able to provide accurate information in preparing the right target strategy and oriented to the main objectives of the company. Performance management based on Balanced
Scorecard can be an alternative in improving the performance of restaurant by applying financially and non-financially interrelated aspects, and consist of four perspectives: financial, customer, internal business process, learning and growth perspective.

According to Krisnawati and Sunardi (2016), Balanced Scorecard is clearly able to reveal the various factors that are driving the achievement of superior financial performance and competitive long term ". In addition, the online survey results on the benefits of Balanced Scorecard in 2016 from 2GC which is an international strategic management consulting firm located in the UK. So the focus in this study is to refine the restaurant's performance management model which previously focused more on financial perspective only to be more comprehensive and effective by identifying important indicators that have both financial and nonfinancial causality in four Balance Scorecard perspectives. So the results of this study is expected to help the Restaurant to formulate a new strategy in measuring the performance of long-term oriented company, including the implementation of operational activities on each individual to achieve corporate goals. In addition, this research also aims to find and develop key success factors that can be used by the management in managing the company more effectively and efficiently.

Based on the above background, it can be describe several research questions below:

1. How does the implementation of Balanced Scorecard can help the management in formulating strategies to improve restaurant performance?

2. What is the relationship of each indicator to the four perspectives used in performance management based on Balanced Scorecard?

\section{Research Objectives}

The objectives of the study are to understand effective performance management and to find the relation of each indicator used in measuring performance according to four perspective of the balanced scorecard. 


\section{Literature Review}

\section{Work Management}

Measurement of performance needs to know the performance implementation. There is a deviation from the predetermined plan, or performance can be done in accordance with the time schedule specified, and performance results have been achieved as expected. The purpose of performance measurement consists of seven points as follows: (i) to organize organizational performance with more structured and organized, (ii) to determine the level of effectiveness and efficiency of an organization's performance, (iii) to assist in determining decisions relating to organizational performance, performance of each part of the organization, and individual performance, (iv) to enhance overall organizational capability with continuous improvement, (v) to help improve performance that activities are focused on the goals and objectives of the work unit program, and (vi) to allocate resources and decision making.

According to Mahfud (2016) performance management is a process to establish. A shared understanding of the things to be achieved and how to achieve them, and is an approach to managing resources in a way that can increase the likelihood of achieving success in the company. According to Albar (2016) performance management is a process designed to improve the performance of organizations, groups, and individuals driven by managers. Performance management includes a continuous review of performance and carried out in conjunction with a work plan, oriented towards the future and tailored specifically to the specific conditions of the organization based on a causal model that links between input and output. So the conclusion is performance management is an activity to review the performance on an ongoing basis to improve and develop an organization to be more effective and efficient.

According to Adiatma (2014), the process of performance management can be explained as follows: (i) Input, performance management requires a variety of inputs that must be managed in order to synergize each

http://ojs.unud.ac.id/index.php/eot other in achieving organizational goals. These inputs include:

a) Human Resources (HR). Performance management requires capital, materials, equipment and technology and methods and working mechanisms;

b) Performance management requires input in the form of human resource capability, both individual and team. HR capability is manifested in the form of knowledge, skills and competence. HR with knowledge and skills is expected to improve the quality of performance process and work result. While the competence required for human resources have the ability in accordance with the needs of the organization so as to provide the best performance;

c) Process. Performance management begins on how to plan the expected goals in the future, and compile all the resources and activities necessary to achieve the goals. Implementation of the plan is monitored and measured progress towards achieving the objectives. Assessment and review are undertaken to correct and determine the necessary steps when there is deviation to the plan. Performance management establishes mutual respect among the parties involved in the performance process. The procedures in performance management are carried out honestly to limit adverse impact on individuals. The performance management process is run transparently primarily towards the people affected by decisions arising and people get the opportunity through the basis of a decision making;

d) Output. Output is a direct result of organizational performance, both in the form of goods and services. The work achieved by the organization should be compared against the expected objectives. Output may be greater or lower than the predetermined goal. If there is a deviation will be a feedback in the planning of future goals and implementation of performance that has been done;

e) Benefits. In addition to paying attention to outputs, performance management also takes into account the benefits of the work. The impact of the work can be positive for the organization, for example, because the success person realize that have an impact to his achievements and improve

e-ISSN: 2407-392X. p-ISSN: 2541-0857 
motivation. Further improve the performance of the organization. But the impact of one's success can be negative, if because of its success it becomes arrogant that will make the working atmosphere become not conducive.

\section{Balance Scorecard}

Balanced scorecard is a performance measurement system that focuses on financial and non financial aspects by looking at four perspectives: financial, customer, learning and employee growth, and internal business processes that can help the organization to translate the vision and strategy into action where all those perspectives are intertwined in a causal relationship. In general, there are four components of business performance measured in the balanced scorecard, i.e., (i) financial perspective, (ii) perspective of customer or consumer, (iii) business internal process perspective, and (iv) learning and growth perspective.

\section{Financial Perspective}

According to Utama (2012), in a business, making money is one of the main goals, so the Financial Perspective is used in the balanced scorecard. The company's performance in generating revenue is one of the important indicators to measure the extent, which the company's strategy benefits companies. The financial perspective has three strategic themes: revenue growth, cost reduction, and asset use. Furthermore financial statements are historical-aggregative indicators that reflect the effects of implementation and execution of strategies in one period. Measuring financial performance will demonstrate the planning and execution of strategies providing fundamental improvements to corporate profits. These improvements are reflected in targets that specifically relate to measurable gains, business growth, and shareholder value. Measurement of financial performance considering the stages of the business life cycle: growth, sustain, and harvest. Each stage has a different target, so the emphasis of measurement is also different which can be explained as follows:

a) Growth is the early stage of the life cycle of a company, which is the company has a

http://ojs.unud.ac.id/index.php/eot product or service that has the greatest growth potential. Here, management is committed to developing a new product or service, building and developing a product or service and production facility, adding operational capabilities, developing systems, infrastructure and distribution networks that will support global relationships, and fostering and developing relationships with customer.

b) Sustain is the second stage in which companies are still investing and reinvesting by hinting for the best returns. At this stage, the company tries to maintain its existing market share, even develop it. The investments are generally directed at developing capacity, and improving operational improvements consistently. Financial targets at this stage are directed at the level of return on investment made. Benchmarks are often used at this stage, such as ROI, ROCE, and EVA.

c) Harvest is the third stage, which the company actually reaps the return on investment in the earlier stages. No more large investments, either expansion or new capacity building, excluding expenses for maintenance and repair of facilities. The main financial objectives in this phase, taken as benchmarks, are maximizing cash inflows and reduction of working capital.

\section{Perspective of Customer}

Management philosophy has shown increased recognition of the importance of customer focus and costumer satisfaction. This perspective is a leading indicator. So, if customers are not satisfied then they will look for other manufacturers that fit their needs. Poor performance from this perspective will decrease the number of customers in the future even though the current financial performance looks good. The customer perspective has two measurement groups namely customer core measurement and cutomer value preposition which can be explained as follows:

\section{Customer Care Measurement}

Customer core measurement has several components of measurement, which can be described as: (i) Market Share reflects 
the company's control overall market, which includes, there are other things: the number of customers, the number of sales, and the volume of sales units; (ii) Customer Retention is Measuring the level at which a company can maintain relationships with consumers; (iii) Customer Acquisition measures the rate, which a business unit is able to attract new customers or win new business; (iv) Customer Satisfaction Assess the level of customer satisfaction associated with specific performance criteria in value proposition; (v) Customer Profitability Measures the net income of a customer or segment after deducting the special costs required to support the customer.

\section{Customer Value Preposition}

Customer value proposition is a performance trigger found in the core value proposition based on the following attributes: (i) Product/service attributes, includes the function of the product or service, price, and quality. Customers have different preferences for the products offered. There is a priority on the function of the product, quality, or cheap price. The company must identify what the customer wants the product to offer. Furthermore, performance measurements are set accordingly; (ii) Customer relationship, concerning the customer's feelings the process of purchasing products offered by the company. This consumer feeling is strongly influenced by the responsiveness and firm commitment to the customer regarding the delivery time. Time is an important component of corporate competition. Consumers usually consider fast and timely completion of orders as a factor important to their satisfaction; (iii) Image and Reputation, describes intangible factors that attract a consumer to connect with the company. Building image and reputation can be done through advertising and promise to keep quality.

\section{Perspective of Internal Business Process}

The internal business process perspective is a reflection of the key processes in the enterprise that can be optimized, to enhance the value proposition that can attract and retain customers. With customers satisfied the services and products, it is expected to have a financial return so as to satisfy the expectations of shareholders and all associated with the company. According to Utama (2012) there are four parts to the internal business process perspective:

a) Operations management process, is the process of receiving orders, working until sending products to customers. In this process, the effectiveness and efficiency of time become the basic principle emphasized.

b) Customer management process, is the process of handling customers from getting customers, maintaining, and increasing value for customers.

c) Innovation process, is an identification process to better understand customer needs as a basis for creating products and services that meet customer needs.

d) Regulatory and social process, is a process to make a positive contribution to the community and the environment around the company.

\section{Perspective of Learning and Growth}

This perspective provides the infrastructure for achieving the three previous perspectives, and for generating long-term growth and improvement. Utama (2012) explains that it is important for a company when investing not only on equipment to produce products/ services, but also investing in infrastructure: human resources, systems and procedures. Measures of financial performance, customers, and internal business processes can reveal a large gap between existing human capabilities, systems, and procedures. To minimize the gap, a business entity must invest in reskilling employees: improving system capabilities and information technology, and reorganizing existing procedures.

\section{Framework of The Study}

The framework for this research can be seen in the Figure 1. 


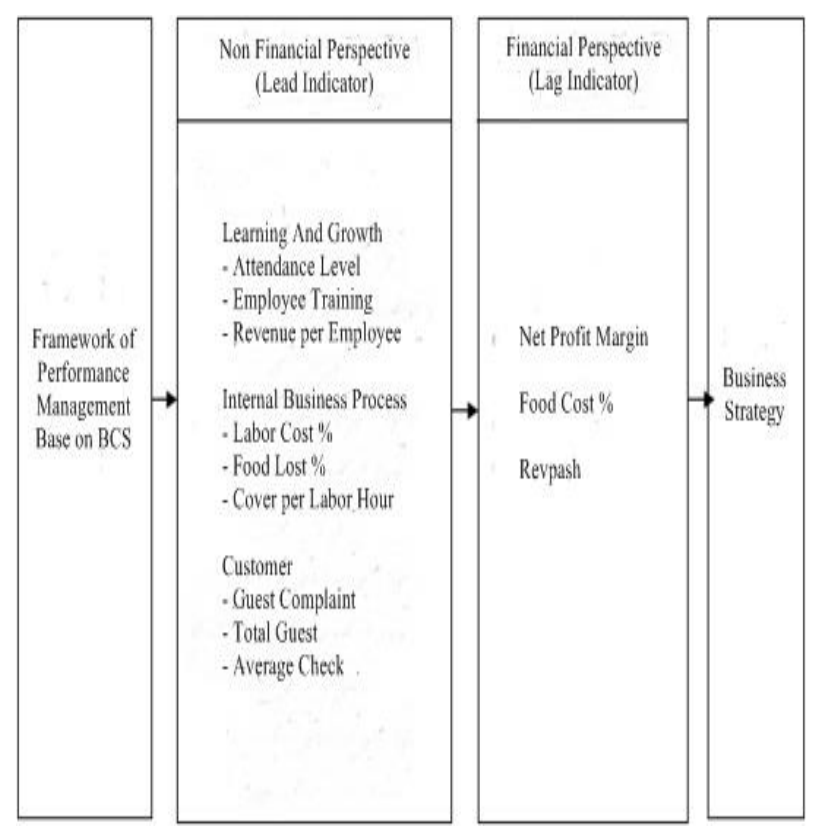

Figure 1. Framework of the Study

\section{Methodology}

The research takes place in Kuta, Bali on July to September 2017. Explorative method used to measure restaurant performance with four perspectives of balanced scorecard. In each of perspectives were chosen the appropriate measuring instrument. The selection of measuring instruments is done with a professional approach (Table 1).

Table 1. Balanced Scorecard Tools in this Study

\begin{tabular}{|c|c|c|}
\hline $\begin{array}{c}\text { Perspective } \\
\text { of Balanced } \\
\text { Scorecard }\end{array}$ & $\begin{array}{l}\text { Measuring } \\
\text { Indicator }\end{array}$ & Definition \\
\hline \multirow{3}{*}{$\begin{array}{l}\text { Perspective } \\
\text { of Learning } \\
\text { and Growth }\end{array}$} & $\begin{array}{l}\text { Employee } \\
\text { absenteeism }\end{array}$ & $\begin{array}{l}\text { indicators that } \\
\text { illustrate the } \\
\text { absence of } \\
\text { employees and } \\
\text { reflect the level } \\
\text { of work } \\
\text { discipline } \\
\text { employees }\end{array}$ \\
\hline & $\begin{array}{l}\text { Employee } \\
\text { training }\end{array}$ & $\begin{array}{l}\text { the number of } \\
\text { trainings } \\
\text { conducted to } \\
\text { improve the } \\
\text { quality and } \\
\text { productivity of } \\
\text { employees }\end{array}$ \\
\hline & $\begin{array}{l}\text { Revenue per } \\
\text { employee }\end{array}$ & $\begin{array}{l}\text { income } \\
\text { contribution that } \\
\text { every employee }\end{array}$ \\
\hline
\end{tabular}

\begin{tabular}{|c|c|c|}
\hline & & $\begin{array}{l}\text { can generate is } \\
\text { the total income } \\
\text { of the restaurant } \\
\text { divided by the } \\
\text { total number of } \\
\text { employees }\end{array}$ \\
\hline \multirow{3}{*}{$\begin{array}{l}\text { Perspective } \\
\text { of Internal } \\
\text { Process }\end{array}$} & $\begin{array}{l}\text { Labor cost } \\
\text { percentage }\end{array}$ & $\begin{array}{l}\text { the percentage of } \\
\text { labor costs is the } \\
\text { overall cost } \\
\text { incurred by the } \\
\text { restaurant to pay } \\
\text { wages, improve } \\
\text { employee } \\
\text { welfare }\end{array}$ \\
\hline & $\begin{array}{l}\text { Food loss } \\
\text { percentage }\end{array}$ & $\begin{array}{l}\text { the ratio used to } \\
\text { measure the } \\
\text { amount of } \\
\text { wasted food in } \\
\text { the production } \\
\text { process of the } \\
\text { total ingredients } \\
\text { used }\end{array}$ \\
\hline & $\begin{array}{l}\text { Cover per } \\
\text { labor hour }\end{array}$ & $\begin{array}{l}\text { productivity level } \\
\text { of restaurant } \\
\text { employees }\end{array}$ \\
\hline \multirow{3}{*}{$\begin{array}{l}\text { Perspective } \\
\text { of Consumer } \\
\text { Satisfaction }\end{array}$} & $\begin{array}{l}\text { Number of } \\
\text { complaint } \\
\text { percentage }\end{array}$ & $\begin{array}{l}\text { number of } \\
\text { complaints with } \\
\text { total buyers who } \\
\text { visit the } \\
\text { restaurant }\end{array}$ \\
\hline & Total guest & $\begin{array}{l}\text { the level of } \\
\text { customer visits at } \\
\text { the Restaurant at } \\
\text { a certain period }\end{array}$ \\
\hline & $\begin{array}{l}\text { Average } \\
\text { check per } \\
\text { cover }\end{array}$ & $\begin{array}{l}\text { the average } \\
\text { spend that } \\
\text { customers spend } \\
\text { when they visit } \\
\text { the restaurant }\end{array}$ \\
\hline \multirow{3}{*}{$\begin{array}{l}\text { Perspective } \\
\text { of Financial }\end{array}$} & $\begin{array}{l}\text { Net profit } \\
\text { margin }\end{array}$ & $\begin{array}{l}\text { the company's } \\
\text { ability to } \\
\text { generate net } \\
\text { income from } \\
\text { total sales }\end{array}$ \\
\hline & Food cost & $\begin{array}{l}\text { all expenses } \\
\text { incurred in order } \\
\text { to produce a } \\
\text { menu with a } \\
\text { certain standard } \\
\text { recipe }\end{array}$ \\
\hline & $\begin{array}{l}\text { Revenue per } \\
\text { available seat } \\
\text { hour }\end{array}$ & $\begin{array}{l}\text { the selling point } \\
\text { of a chair } \\
\text { available for sale } \\
\text { by the restaurant } \\
\text { every hour }\end{array}$ \\
\hline
\end{tabular}


The Table 1 shows that for each perspective there are three set of indicators. Pearson correlation is used to analyse the relation of all perspectives. For each perspective represented by one of the indicator and form model of relation as can be seen in the Table 2 below.

Table 2. Perspectives and Relation Models

\begin{tabular}{|c|c|c|c|c|}
\hline $\begin{array}{c}\text { Mode } \\
1\end{array}$ & $\begin{array}{l}\text { Perspect } \\
\text { ive of } \\
\text { Learning } \\
\text { and } \\
\text { Growth }\end{array}$ & $\begin{array}{l}\text { Perspect } \\
\text { ive of } \\
\text { Internal } \\
\text { Process }\end{array}$ & $\begin{array}{l}\text { Perspect } \\
\text { ive of } \\
\text { Consum } \\
\text { er } \\
\text { Satisfact } \\
\text { ion } \\
\end{array}$ & $\begin{array}{l}\text { Perspect } \\
\text { ive of } \\
\text { Financi } \\
\text { al }\end{array}$ \\
\hline $\begin{array}{l}\text { Relati } \\
\text { on } \\
\text { model } \\
1\end{array}$ & $\begin{array}{l}\text { Employe } \\
\mathrm{e} \\
\text { absentee } \\
\text { ism }\end{array}$ & $\begin{array}{l}\text { Labor } \\
\text { cost } \\
\text { percenta } \\
\text { ge }\end{array}$ & $\begin{array}{l}\text { Number } \\
\text { of } \\
\text { complai } \\
\text { nt } \\
\text { percenta } \\
\text { ge }\end{array}$ & $\begin{array}{l}\text { Net } \\
\text { profit } \\
\text { margin }\end{array}$ \\
\hline $\begin{array}{l}\text { Relati } \\
\text { on } \\
\text { model } \\
2\end{array}$ & $\begin{array}{l}\text { Employe } \\
\mathrm{e} \\
\text { training }\end{array}$ & $\begin{array}{l}\text { Food } \\
\text { loss } \\
\text { percenta } \\
\text { ge }\end{array}$ & $\begin{array}{l}\text { Total } \\
\text { guest }\end{array}$ & $\begin{array}{l}\text { Food } \\
\text { cost }\end{array}$ \\
\hline $\begin{array}{l}\text { Relati } \\
\text { on } \\
\text { model } \\
3\end{array}$ & $\begin{array}{l}\text { Revenue } \\
\text { per } \\
\text { employe } \\
\text { e }\end{array}$ & $\begin{array}{l}\text { Cover } \\
\text { per } \\
\text { labor } \\
\text { hour }\end{array}$ & $\begin{array}{l}\text { Average } \\
\text { check } \\
\text { per } \\
\text { cover }\end{array}$ & $\begin{array}{l}\text { Revenu } \\
\text { e per } \\
\text { availabl } \\
\text { e seat } \\
\text { hour }\end{array}$ \\
\hline
\end{tabular}

\section{Results and Discussion}

The measurement of each perspective on each model can be explained as follows:

\section{The First Model}

The first model consists of several indicators on each balanced scorecard perspective, collected from data obtained for the 2016 period, see Figure 1.

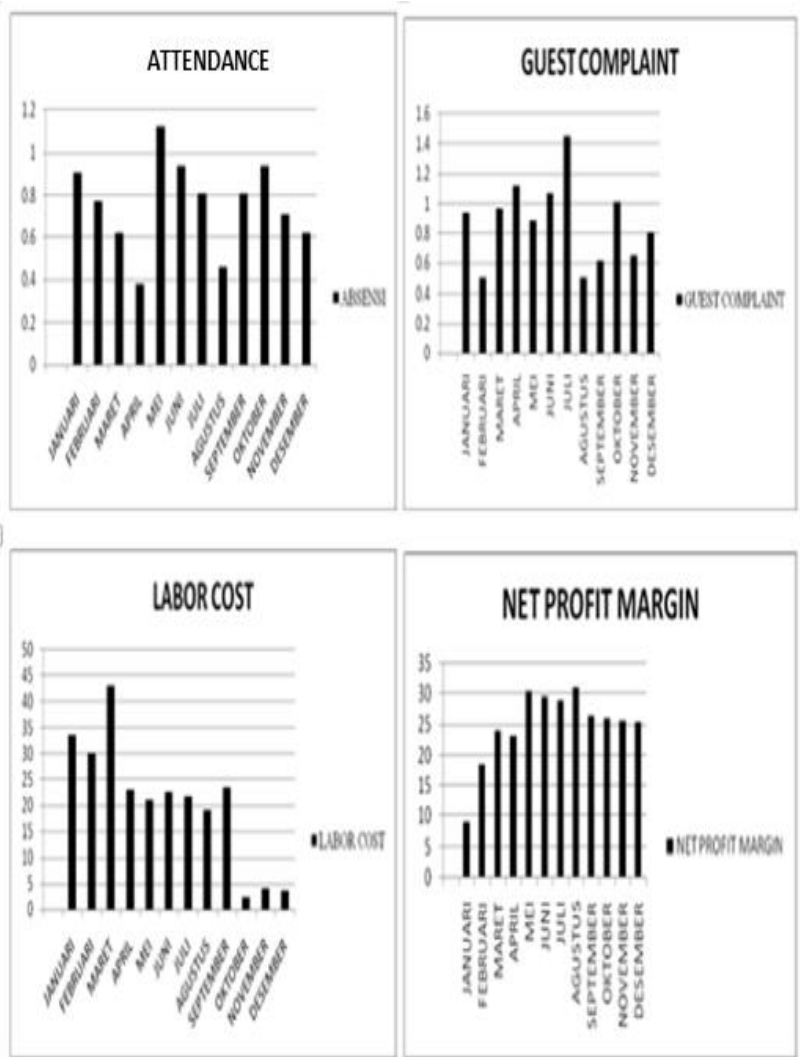

Figure 1. Performance of Attendance, Labor Cost Percentage, Guest Complaint Percentage, Net Profit Margin in 2016

It can be seen that the average employee absenteeism (attendance) is 0.76 in the period of 2016 with the highest absentee rate in May 2016 is 1.12 and the lowest level in april 2016 is at number 0.38 . on the guest complaint indicator the average percentage of customer complaints during the period 2016 was 0.88 percent. And the highest percentage value occurred in July 2016 with the number 1.45 percent and the lowest percentage that is in February and August 2016 with the number of 0.51 percent. The average percentage of labor costs for the period of 2016 was 20.71 percent with the highest value in March 2016 of 43.05 percent and the lowest value in October 2016 at 2.40 percent. And the average net profit margin or net profit value for the period of 2016 is 24.93 percent with the highest value in August 2016 and the lowest value is 9.15 in January 2016. Simple linear correlation analysis of each indicator in model 
one to prove the relationship between each indicator used.

Table 2. Correlation of the First Model

\begin{tabular}{|c|c|c|c|c|c|}
\hline & & $\begin{array}{c}\text { Rand: } \\
\vdots\end{array}$ & $\begin{array}{c}\text { Gant } \\
\text { Condat: }\end{array}$ & Lim & 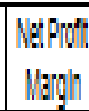 \\
\hline \multirow{3}{*}{ Atterdanke } & Prancort:ilm & 1 & 477 & -12 &.$M$ \\
\hline & 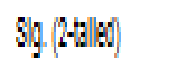 & & $M$ & $M$ & 9.4 \\
\hline & $\mathbb{N}$ & 12 & 12 & 12 & 12 \\
\hline \multirow[t]{3}{*}{ Gat On:lit } & PHom Wrath & 147 & 1 & 3 & 97 \\
\hline & 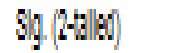 & $M$ & & 018 & 816 \\
\hline & $\mathbb{N}$ & 12 & 12 & 12 & 12 \\
\hline \multirow[t]{3}{*}{ LWW: } & Panconot:in & $M$ & 87 & 1 & .96 \\
\hline & Slg. (2allatin) & $M$ & 0.18 & & 018 \\
\hline & $\mathbb{N}$ & 12 & 12 & 12 & 12 \\
\hline \multirow[t]{3}{*}{ 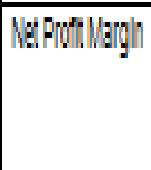 } & PHom Oreath & $M$ & 078 & -38 & 1 \\
\hline & 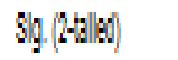 & at: & 80 & 018 & \\
\hline & $\mathbb{N}$ & 12 & 12 & 12 & 12 \\
\hline
\end{tabular}

Based on the table, it can be explained that the absenteeism level indicator is positively correlated with guest complaint percentage or the percentage of customer complaints correlation value of 0.417 . In guest complaint indicators or percentage of customer complaints are positively correlated with labor cost percentage or labor cost percentage with correlation value of 0.387 . And labor cost percentage or labor cost percentage is negatively correlated with net profit margin or net profit value with correlation value of 0.395 .

\section{The Second Model}

The second model consists of several indicators in measuring the performance of restaurant in the period 2016 with the following data.

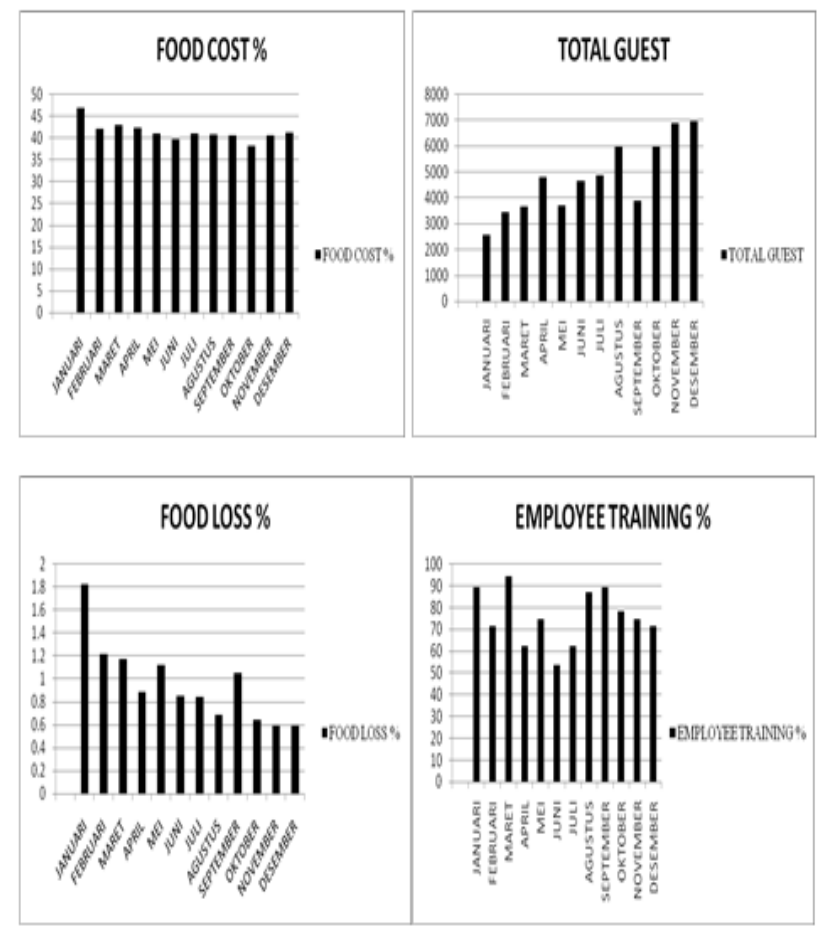

Figure 2. Profile of Percentage of Food Cost Percentage, Total Guest, Food Loss Percentage, and Employee Trained

The Figure 2 shows that the performance of restaurant in the period 2016 measured by some indicators that is, the average percentage of the cost of food restaurant is 41.53 percent with the highest value of 46.93 percent in January 2016 and the lowest value is 38.17 in October 2016. For an average customer total of 4784 subscribers in the period of 2016, with the highest number of 6967 in December 2016 and the lowest number of 2562 in January 2016. For food loss percentage or percentage of foodstuffs damaged and wasted in the period of 2016 with an average value of 0.96 of the total cost of food, and the highest value of 1.83 in January 2016 and the lowest value of 0.59 in November and December 2016. The average employee training or percentage of the number of employees trained in the period 2016 is 75.87 percent with the value the highest percentage of 94.64 in March 2016 and the lowest percentage of 53.57 in June 2016. Simple linear correlation analysis of each indicator in model two to prove the relationship between each indicator used. 
Table 3. Correlation Results of the Second Model

\begin{tabular}{|ll|r|r|r|r|}
\hline & & & & & $\begin{array}{c}\text { Em ployee } \\
\text { Training }\end{array}$ \\
\hline Food Cost & Pearson Correlation & 1 &,$- 607^{\star}$ &, $830^{* *}$ &, 364 \\
& Sig. (2-tailed) & &, 037 &, 001 &, 245 \\
& $\mathrm{~N}$ & 12 & 12 & 12 & 12 \\
\hline Tot guest & Pearson Correlation &,$- 607^{\star}$ & 1 &,$- 916^{* *}$ &,- 251 \\
& Sig. (2-tailed) &, 037 & &, 000 &, 431 \\
& $\mathrm{~N}$ & 12 & 12 & 12 & 12 \\
\hline Food loss & Pearson Correlation &, $830^{* *}$ &,$- 916^{* *}$ & 1 &,- 378 \\
& Sig. (2-tailed) &, 001 &, 000 & &, 002 \\
& $\mathrm{~N}$ & 12 & 12 & 12 & 12 \\
\hline Employee Training & Pearson Correlation &, 364 &,- 251 &,- 378 & 1 \\
& Sig. (2-tailed) &, 245 &, 431 &, 002 & \\
& $\mathrm{~N}$ & 12 & 12 & 12 & 12 \\
\hline
\end{tabular}

Based on the table, the indicator of the total guest is negatively correlated with food cost percentage with correlation value of 0.607. In food loss percentage indicator is negatively correlated with total guest with correlation value equal to -0.916. Employee trained percentage indicator is negatively correlated with food loss percentage with correlation value of -0.378 .

\section{The Third Model}

The third model consists of several indicators in measuring the performance of restaurant with data recapitulation in the period of 2016.
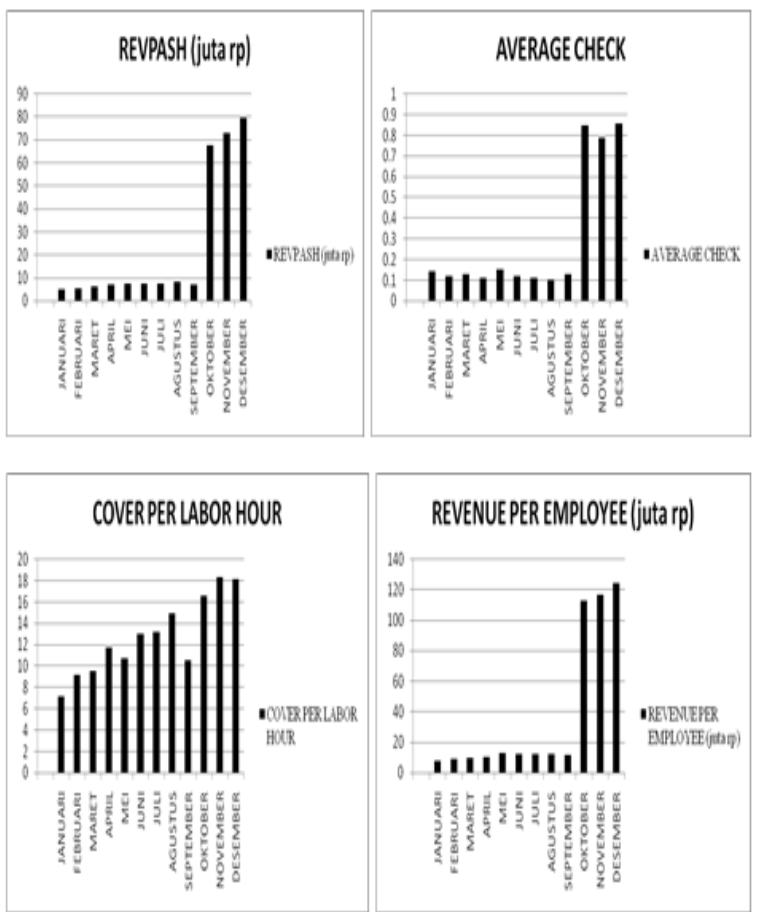

Figure 3. Profile of Percentage of Revpash, Average Check, Cover per labor hour, and Revenue Per Employee Revenue Per Employee
The Figure 3 shows that the value of revenue per available seat hour or the selling price of seats every hour at restaurant with an average value of Rp. 23,415,261.33 in the period of 2016. The highest value is Rp.79.657.236,51 in December 2016 and the lowest value is Rp.4.770.180,68 in January 2016. For average check or average purchase in the restaurant in the period 2016 is $\mathrm{Rp}$. 300,921.44 with the highest value reached Rp. 857,513.24 in December 2016 and the lowest value of Rp. 102,386,51 in August 2016. On the cover per labor hour indicator or the number of customers served by the waiter every hour, the average value in the period of 2016 was 12.76 customers, with the highest score being 18 in November and December 2016 and the lowest value ie 7 in january 2016. On the indicator of revenue per employee or per employee grace in the period of 2016, with an average value of $\mathrm{Rp}$. $37,595,107,74$ with the highest value of $\mathrm{Rp}$. 124.464.474,23 in December 2016, and the lowest value of Rp. 7,950,301 in the month of january 2016. Simple linear correlation analysis of each indicator in model three to prove the relationship between each indicator used.

Table 4. Correlation Results of the Third Model

\begin{tabular}{|ll|r|r|r|r|}
\hline & Revpash & $\begin{array}{c}\text { Average } \\
\text { check }\end{array}$ & \multicolumn{1}{c|}{ CPLH } & $\begin{array}{c}\text { Revenue Per } \\
\text { Employee }\end{array}$ \\
\hline Revpash & Pearson Correlation & 1 &, $994^{* *}$ &, $840^{* *}$ &, $999^{* *}$ \\
& Sig. (2-tailed) & &, 000 &, 001 &, 000 \\
& $\mathrm{~N}$ & 12 & 12 & 12 & 12 \\
\hline Average check & Pearson Correlation &, $994^{* *}$ & 1 &, $800^{* *}$ &, $997^{* *}$ \\
& Sig. (2-tailed) &, 000 & &, 002 &, 000 \\
& $\mathrm{~N}$ & 12 & 12 & 12 & 12 \\
\hline CPLH & Pearson Correlation &, $840^{* *}$ &, $80 *^{* *}$ & 1 &, $837^{* *}$ \\
& Sig. (2-tailed) &, 001 &, 002 & &, 001 \\
& $\mathrm{~N}$ & 12 & 12 & 12 & 12 \\
\hline Revenue Per Employee & Pearson Correlation &, $999^{* *}$ &, $997^{* *}$ &, $837^{* *}$ & 1 \\
& Sig. (2-tailed) &, 000 &, 000 &, 001 & \\
& $\mathrm{~N}$ & 12 & 12 & 12 & 12 \\
\hline
\end{tabular}

Based on the Table 4, the average check indicator is positively correlated with revpash with a correlation value of 0.994 . The indicator of cover per labor hour was positively correlated with the average check with a correlation value of 0.800 and indicator of revenue per employee is positively correlated with cover per labor hour with correlation value of 0.837 . 


\section{Conclusion and Implication}

\section{Concluson}

a) The first model showed attendance level indicator is positively correlated with guest complaint percentage or customer complaint percentage of correlation value of 0.417. Guest complaint percentage indicator is positively correlated with labor cost percentage with correlation value of 0.387 . Labor cost percentage indicator is negatively correlated with net profit margin with correlation value of 0.395, which indicates that the performance of restaurant is good.

b) The second model showed the total guest indicator is negatively correlated with food cost percentage with a correlation value of -0.607 . Food loss indicator is negatively correlated with total guest with correlation value of -0.916. Employee trained percentage indicator is negatively correlated with food loss percentage with correlation value of -0.378 .

c) The third model showed the average check indicator is positively correlated with revpash with a correlation value of 0.994 . The cover per labor hour indicator was positively correlated with the average check with a correlation value of 0.800 and indicator of revenue per employee is positively correlated with cover per labor hour with correlation value of 0.837 .

\section{Implication for Further Research}

a) Implementation of Balanced Scorecard can be considered as a performance management framework by considering the financial and non-financial aspects, so that ultimately can assist the Management in making improvements to the company.

b) From a financial perspective, management needs to develop indicators in measuring financial performance, especially those that have an effect on the value of net income, so that the value of net income can be maximized.

c) On the customer's perspective, management should begin measuring the average check to determine the selling price that corresponds to the average customer spending in the restaurant, as an evaluation tool in improving the quality of service.

d) On the internal perspective of the process, management needs to clearly identify the level of productivity of each employee and the effectiveness of the workforce.

e) In the learning and growth perspective, management needs to make measurements of the results of the training that has been done, so it can be known the level of effectiveness of the training that has been given.

\section{References}

Adiatma, Y. (2014) No Title. Available at: http://yudaadiatma.blogspot.co.id/2014/0

3/. 21 Agustus 2017 (Accessed: 21 August 2017).

Krisnawati, N. and Sunardi, R. (2016) Kebangkitan Merek Lokal Industri Perhotelan di Indonesia. Yogyakarta: Deepbulish.

Lynn, C. (2017) Food Service Industry: Labor Cost Standards. Available at: http://smallbusiness.chron.com/foodservice-industry-labor-cost-standards13911.html.

Rangkuti, F. (2011) SWOT: Balanced Scorecard. Gramedia Pustaka Utama.

Streanise, P. P. (2012) Dining room and banquet management trird edition. Jakarta: Thomson.

Utama, R. (2012) Analisis Kinerja Menggunakan Balanced Scorecard. 